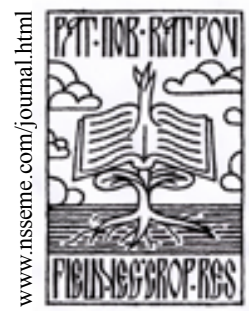

\title{
Agro-biological Traits of Common Millet (Panicum miliaceum L.) Genotypes in Regular and Stubble Crop
}

\author{
Vladimir Sikora • Vladimir Filipović • Janoš Berenji • Vera Popović
}

\author{
received: 27 March 2013, accepted: 29 April 2013 \\ published online: 28 May 2013 \\ () 2013 IFVC \\ doi:10.5937/ratpov50-3662
}

\begin{abstract}
Summary: Agro-biological traits of common millet (Panicum miliaceum L.) genotypes were studied on experimental lots of the Institute of Field and Vegetable Crops in Bački Petrovac, Serbia in 2009 and 2010. The study included 16 genotypes of millet grown and used in selection programs in Serbia and abroad. Crops in trials were based on regular and stubble crops. A significant variability appeared during and at the end of growing season in the number of days from emergence to earing of some genotypes of millet, plant height, grain yield, 1000-grain weight and test weight of the test material, and it can be used as a good basis for further work on breeding and improvement of common millet. Cluster analysis identified genotypes with high performance for yield per plant, but also good stability of other studied parameters. Studies have shown that the genetic factor had significant effect on realized values of all tested traits. The difference between the yield of millet in regular and stubble crops was also statistically significant. Out of 9 varieties and lines of millet, 3 of them achieved a higher yield in stubble crops. From the point of agro-biological traits, 2010 was more favourable for the production of millet.

Keywords: agro-biological traits, common millet, crop yield, cluster analysis, genotypes, stubble crops
\end{abstract}

\section{Introduction}

Common millet is grown in the world on $35,657,612$ hectares with an average yield of 2.62 t ha ${ }^{-1}$, in Europe on 765,774 hectares with lower yield of $1.22 \mathrm{t} \mathrm{ha}^{-1}$, in Serbia on estimated area of 1,200 hectares with an average yield of $2.40 \mathrm{t}$ ha ${ }^{-1}$ (Malešević et al. 2011). Common millet is used in human nutrition (mainly as a bio-food) and in animal nutrition (food for birds) (Berenji 2012). Within the program of millet production improvement (Berenji 1990, 1993, 1994, Starčević \& Berenji 1994), the greatest attention was dedicated to the study of common millet. Selection of 1,160 genotypes originating from India, USA and Hungary, amended by local populations collected from Vojvodina and Slovenia, was used as

V. Sikora* • J. Berenji • V. Popović

Institute of Field and Vegetable Crops, Maksima Gorkog 30, 21000

Novi Sad, Serbia

e-mail: vladimir.sikora@nsseme.com

V. Filipović

Institute for Medicinal Plant Research "Dr Josif Pančić", T. Košćuška 1, 11000 Belgrade, Serbia starting material. Due to its agro-biological traits, it could become a very important stubble crop (Berenji \& Kišgeci 1988). Perspective of growing common millet in Vojvodina primarily depends on the completion of planned land under irrigation systems. Common millet is one of the few plants which can be grown as stubble crop, because of the short growing season, giving good yields (Berenji \& Kišgeci 1988). Successful stubble crop sowing due to prolonged summer droughts is possible only under irrigation. There are two varieties in Serbia of short stature which belong to generative types, i.e. suitable for grain production, and less suitable for the herbage production or hay. Biserka (white coloured grain) and Rumenka (red coloured grain) are the first two common millet varieties developed at the Institute of Field and Vegetable Crops, Novi Sad, Serbia and released in 1991 (Berenji et al. 2000, 2008). Both are characterized by short

\footnotetext{
Acknowledgements:

Experiment needed for this work is part of the project TR 31073, financed by the Ministry of Education, Science and Technological Development of the Republic of Serbia.
} 
vegetation (which makes them suitable also for the production as stubble crop), short stems (as a factor of tolerance to lodging) and high yields. The world's largest contribution to selections was in countries where common millet is most grown, such as India and USA (Manoharan \& Sivasubramanian 1982, Baltensperger 2002, Karam et al. 2004, Upadhyaya et al. 2011). Crossing of various genotypes and examination of a large number of qualitative and quantitative indicators has been the subject of many studies (Barbeau \& Hilu 1993, Zeller 2000, Heyduck et al. 2008, Cho et al. 2010, Hunt et al. 2011). The aim of this study was to determine millet genotypes productivity for grain, based on regular and stubble crop on yield and individual agro-biological traits.

\section{Materials and Methods}

Field trials were set up during 2009 and 2010 at the experimental plots of the Institute of Field and Vegetable Crops, Novi Sad, Serbia, at the

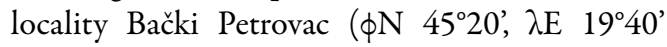
$89 \mathrm{~m}$ a.s.l.). The experiment was established on chernozem soil and testing included 16 genotypes of common millet of different origin. According to meteorological data obtained in 2009 , the total precipitation in the growing season was lower, while the average monthly temperature was higher than in 2010. Such a relation and layout is more favourable for millet plants developed in the second year, when higher grain yield was recorded (Figure 1).

The experiment was based on a randomized complete block design in four replications with randomized variants layout. Elementary plots were situated in four rows of total area of $20 \mathrm{~m}^{2}(2 \mathrm{x}$ $10 \mathrm{~m}$ ), with a row spacing of $50 \mathrm{~cm}$ and spacing between plants in row $5 \mathrm{~cm}$. Cultural practices recommended for conventional common millet production were applied (Berenji 1993). Regular sowing was performed on May 11, 2009 and May 15,2010 . The stubble crop was sown on June 19 , 2009 and July 12, 2010.

Number of days from emergence to earing and plant height at earing stage were recorded as morphological traits parameter of earliness. Plants were harvested at the time of physiological maturity of grain, which in both years was in the last week of August. After manual harvest, yield and grain moisture were measured. The total yield of some genotypes $\left(\mathrm{kg} \mathrm{ha}^{-1}\right)$ was converted to storage grain moisture of $13 \%$. Quality parameters were measured (1000-grain weight $[\mathrm{g}]$ and test weight

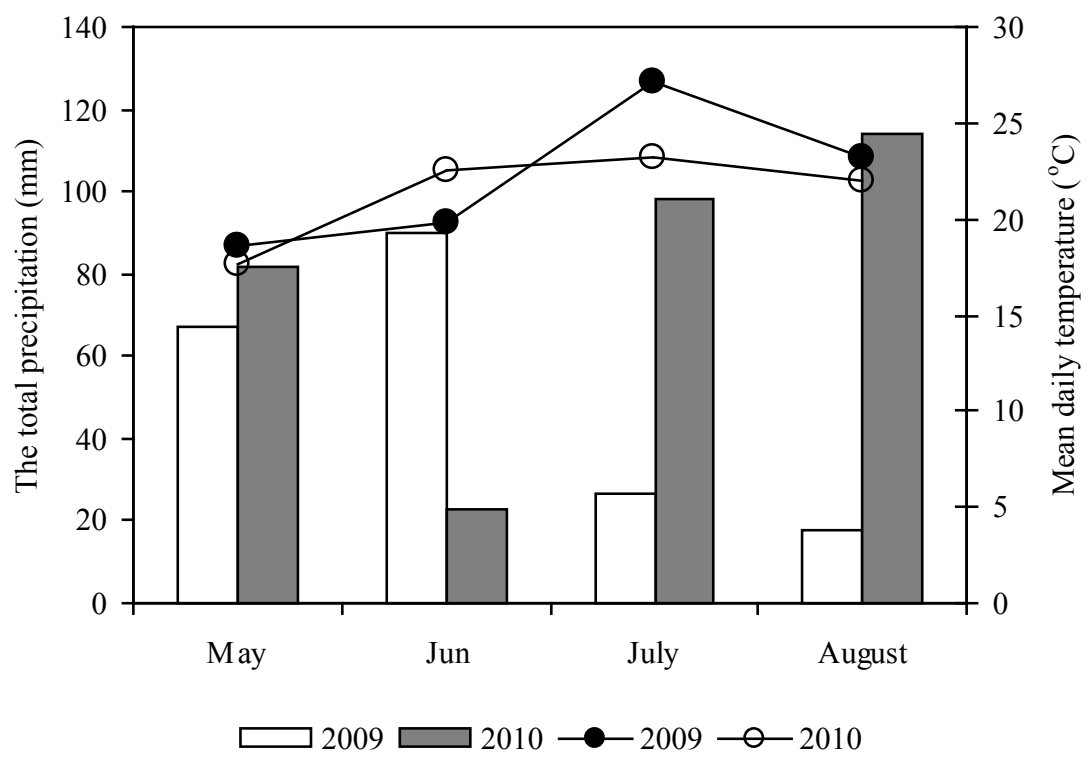

Figure 1: Mean daily temperature $\left({ }^{\circ} \mathrm{C}\right)$ and total precipitation $(\mathrm{mm})$ during the growing season at the experimental site in Bački Petrovac in 2009 and 2010

Graf 1: Srednje dnevne temperature $\left({ }^{\circ} \mathrm{C}\right)$ i ukupne padavine $(\mathrm{mm})$ tokom vegetacije na lokalitetu Bački Petrovac u 2009. i 2010. godini 
[kg]) after processing grain. Statistical analysis used methods of descriptive statistics: the minimum and maximum values, mean value, standard deviation and coefficient of variation. Statistical importance of differences between the calculated mean values was obtained using the model analysis of variance (ANOVA) of statistical package Statistica 10 for Windows. All reviews on the significance were carried out on the F-test and Duncan's test, a test for the risk threshold of $5 \%$ and $1 \%$.

\section{Results and Discussion}

Since we cannot predict the weather conditions for seed production in a certain area, it is very important to follow the variation of environmental factors and to recognize their impact on physiological processes that determine yield and seed quality (Popović et al. 2013, Sikora et al. 2011). From the point of agro-biological traits, 2010 was more favourable for the production of millet.

\section{The varietal experiments}

In this two-year study, an average of the highest grain yields $\left(4,491 \mathrm{~kg} \mathrm{ha}^{-1}\right)$, was achieved by genotype 9304 (Table 1). Eight of sixteen genotypes achieved grain yield higher than $4,000 \mathrm{~kg}$ per hectare. Obtained results for the two local varieties Biserka and Rumenka are consistent with their productivity features, which are from 3,200 to 3,800 $\mathrm{kg} \mathrm{ha}^{-1}$ (Berenji 2012). Ten studied genotypes had plants higher than $100 \mathrm{~cm}$. Genotype 436623 had the average highest plant height of $119 \mathrm{~cm}$. This genotype was characterized by the second position of the grain yield on the ranks $\left(4,422 \mathrm{~kg} \mathrm{ha}^{-1}\right)$ and the longest period from emergence to earing, which lasted an average of 49 days. According to results regarding 1000-grain weight, given genotype exhibited significantly less weight than other genotypes. The minimum number of days from emergence to earing was recorded at the genotype 9307 , only 38 days. This genotype had the fourth-ranking grain yield $(4,320$

Table 1. Agro-biological traits of common millet collection

Tabela 1. Agrobiološke osobine kolekcije običnog prosa

\begin{tabular}{|c|c|c|c|c|c|}
\hline Variety & $\begin{array}{c}\text { Yield / } \\
\text { Prinos } \\
\left(\mathrm{kg} \mathrm{ha}^{-1}\right)\end{array}$ & $\begin{array}{c}\text { Plant } \\
\text { height/ } \\
\text { Visina biljke } \\
(\mathrm{cm})\end{array}$ & $\begin{array}{c}\text { Emergence/ } \\
\text { earing/ } \\
\text { (days) }\end{array}$ & $\begin{array}{c}\text { 1000-grain } \\
\text { weight/ } \\
\text { Masa } 1000 \text { zrna } \\
\text { (g) }\end{array}$ & $\begin{array}{c}\text { Test } \\
\text { weight/ } \\
\text { Hektolitarska } \\
\text { masa } \\
(\mathrm{kg})\end{array}$ \\
\hline Biserka & $4,051^{\mathrm{ab}}$ & $101^{\mathrm{a}}$ & $40^{\mathrm{ab}}$ & $7.7^{\mathrm{ab}}$ & $93.1^{\mathrm{a}}$ \\
\hline Rumenka & $3,694^{\mathrm{d}}$ & $102^{\mathrm{a}}$ & $43^{\mathrm{cd}}$ & $6.9^{c}$ & $94.0^{\mathrm{d}}$ \\
\hline GKI Piroška & $3,030^{\mathrm{f}}$ & $86^{d}$ & $40^{\mathrm{ab}}$ & $7.6^{\mathrm{ab}}$ & $94.6^{\mathrm{d}}$ \\
\hline Fertodi 2 & $4,121^{a}$ & $118^{\mathrm{c}}$ & $44^{\mathrm{d}}$ & $6.4^{\mathrm{d}}$ & $100.1^{\mathrm{c}}$ \\
\hline Millet & $3,652^{\mathrm{d}}$ & $118^{\mathrm{c}}$ & $47^{\mathrm{ef}}$ & $6.3^{\mathrm{d}}$ & $94.9^{\mathrm{d}}$ \\
\hline 9210 & $4,370^{\mathrm{c}}$ & $102^{\mathrm{a}}$ & $41^{\mathrm{ac}}$ & $7.2^{\mathrm{c}}$ & $93.1^{\mathrm{a}}$ \\
\hline 9304 & $4,491^{\mathrm{e}}$ & $109^{\mathrm{b}}$ & $45^{\mathrm{de}}$ & $7.5^{\mathrm{b}}$ & $91.3^{\mathrm{bc}}$ \\
\hline 9307 & $4,320^{\mathrm{c}}$ & $94^{c}$ & $38^{\mathrm{b}}$ & $7.3^{\mathrm{bc}}$ & $91.8^{\mathrm{bc}}$ \\
\hline 9308 & $3,885^{b c}$ & $93^{c}$ & $46^{\mathrm{e}}$ & $7.9^{\mathrm{a}}$ & $92.7^{\mathrm{ab}}$ \\
\hline NE1 & $2,926^{\mathrm{f}}$ & $92^{\mathrm{cd}}$ & $47^{\mathrm{ef}}$ & $6.8^{\mathrm{cd}}$ & $91.6^{\mathrm{bc}}$ \\
\hline Sunrise & $3,881^{b c}$ & $103^{\mathrm{ab}}$ & $46^{\mathrm{c}}$ & $7.5^{\mathrm{b}}$ & $90.5^{c}$ \\
\hline Early bird & $4,150^{a}$ & $95^{c}$ & $46^{\mathrm{c}}$ & $7.6^{\mathrm{ab}}$ & $92.9^{\mathrm{ab}}$ \\
\hline Huntsman & $3,778^{\mathrm{cd}}$ & $107^{\mathrm{b}}$ & $46^{\mathrm{e}}$ & $7.3^{b c}$ & $93.9^{\mathrm{d}}$ \\
\hline Sunup & $4,130^{a}$ & $107^{\mathrm{b}}$ & $39^{\mathrm{b}}$ & $7.1^{\mathrm{c}}$ & $91.1^{c}$ \\
\hline 436623 & $4,422^{\mathrm{c}}$ & $119^{\mathrm{c}}$ & $49^{\mathrm{f}}$ & $5.0^{\mathrm{c}}$ & $92.0^{\mathrm{bc}}$ \\
\hline \multirow[t]{2}{*}{ Kornberger } & $2,049^{f}$ & $91^{\mathrm{cd}}$ & $30^{\mathrm{g}}$ & $7.8^{\mathrm{ab}}$ & $91.4^{\mathrm{bc}}$ \\
\hline & $* *$ & ** & ** & ${ }^{* *}$ & ** \\
\hline
\end{tabular}

${ }^{* *}$ Difference between varieties was significant, $\mathrm{p} \leq 0.01 /$ Razlika između sorti je signifikantna, $\mathrm{p} \leq 0.01$ Different letters mark significant differences between varieties, according to Duncan's test, $p \leq 0.05$ /

Različitim slovima su označene značajne razlike između sorti, prema Dankanovom testu, $\mathrm{p} \leq 0.05$ 
$\mathrm{kg} \mathrm{ha}^{-1}$ ), which indicates that there was no strong correlation between the two tested variables. 1000 -grain weight in some of the previous studies was $4.269 \mathrm{~g}$ (James et al. 2011) and from 6.5 to $7.0 \mathrm{~g}$ (Berenji 2012), which is different from our results. Genotype Kornberger had the highest 1000-grain weight, which achieved the lowest yield of $2,049 \mathrm{~kg} \mathrm{ha}^{-1}$. Recorded test weight ranged from 90.5 (Sunrise) to $100.1 \mathrm{~kg}$ (Fertodi 2). The values of all examined variable collection of traits of common millet recorded statistically very significant difference. These results are consistent with Baltensperger et al. (1995a, 1995b, 1997, 2004) who stated the results of many years of research and possible genetic potential and other agro-biological traits of genotypes Huntsman, Early bird, Sunrise and NE1. In his research, Jacobs (2001) states that 9 genotypes had an average twice the lower yields compared to the yields achieved in our studies.

\section{Cluster analysis}

Dendrogram obtained by cluster analysis shows adequate grouping of 16 different genotypes of common millet according to grain yield which characterized them and highlighted into four groups (Figure 2). The first cluster included 4 genotypes (9210, 9307, 436623 and 9304), which are characterized by the highest average grain yield of $4,371 \mathrm{~kg} \mathrm{ha}^{-1}$ (genotype 9210) to $4,491 \mathrm{~kg} \mathrm{ha}^{-1}$ (genotype 9304). The second cluster is composed of genotypes Biserka, Fertodi 2, Sunup and Early bird, which was characterized by lower grain yields. Interval of achieved yields of this group of genotypes was in range from $4,051 \mathrm{~kg} \mathrm{ha}^{-1}$ (genotype Biserka) to $4,150 \mathrm{~kg} \mathrm{ha}^{-1}$ (genotype Early bird). The third cluster consists of two genotypes which made almost identical two-year average yield $(3,885 \mathrm{~kg}$ $\mathrm{ha}^{-1} 9308$ and $3,881 \mathrm{~kg} \mathrm{ha}^{-1}$ Sunrise). Grain yields in the range from 3,652 to $3,778 \mathrm{~kg} \mathrm{ha}^{-1}$ represent

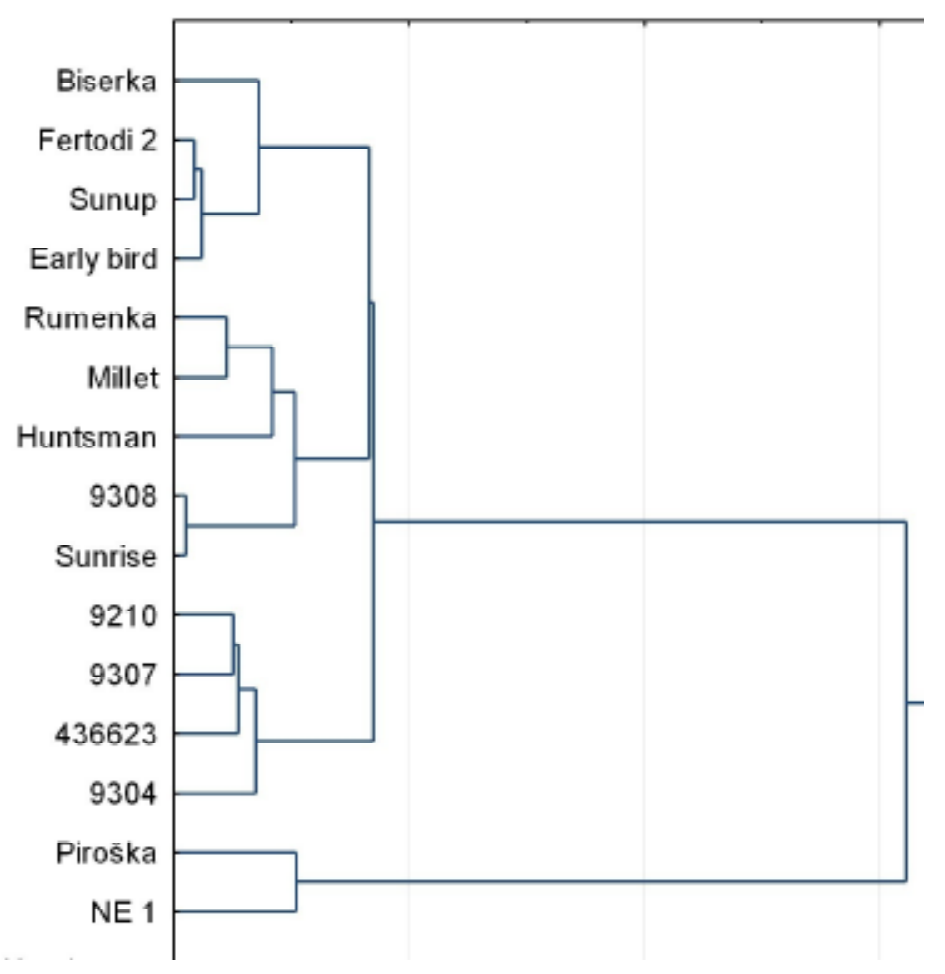

Figure 2: Dendrogram of grain yield of 16 genotypes of common millet (Panicum miliaceum L.)

Graf 2. Dendrogram za prinos zrna 16 genotipova običnog prosa (Panicum miliaceum L.) 
Table 2. Descriptive statistics for agro-biological traits collection of common millet Tabela 2. Deskriptivna statistika za agrobiološke osobine kolekcije običnog prosa

\begin{tabular}{|c|c|c|c|c|c|}
\hline & $\begin{array}{l}\text { Yield / } \\
\text { Prinos } \\
\left(\mathrm{kg} \mathrm{ha}^{-1}\right)\end{array}$ & $\begin{array}{c}\text { Plant } \\
\text { height / } \\
\text { Visina biljke } \\
(\mathrm{cm}) \\
\end{array}$ & $\begin{array}{c}\text { Emergence/ } \\
\text { Earing/ } \\
\text { Broj dana od klasanja } \\
\text { (days) }\end{array}$ & $\begin{array}{c}\text { 1000-grain } \\
\text { weight / } \\
\text { Masa } 1000 \text { zrna } \\
\text { (g) }\end{array}$ & $\begin{array}{c}\text { Test } \\
\text { weight / } \\
\text { Hektolitarska masa } \\
(\mathrm{kg})\end{array}$ \\
\hline Min & 2,049 & 86 & 30 & 5.0 & 90.5 \\
\hline Max & 4,491 & 119 & 49 & 7.9 & 100.1 \\
\hline I & 2,442 & 33 & 19 & 2.9 & 9.6 \\
\hline$x \pm s_{x}$ & $3,809 \pm 628.1$ & $102 \pm 9.9$ & $43 \pm 4.6$ & $7.1 \pm 0.7$ & $93.0 \pm 2.2$ \\
\hline $\mathrm{Cv}(\%)$ & 16.3 & 9.7 & 10.7 & 9.9 & 2.4 \\
\hline
\end{tabular}

the fourth cluster consisting of three genotypes (Rumenka, Millet and Huntsman). Two genotypes (GKI Piroska and NE1) are characterized by twoyear average lower yields, compared to above mentioned genotypes. Yields of the fifth cluster were $3,030 \mathrm{~kg} \mathrm{ha}^{-1}$ GKI Piroska and 2,926 $\mathrm{kg} \mathrm{ha}^{-1}$ NE1. The last cluster represents only one genotype Kornberger, which achieved the lowest yield of 2,049 $\mathrm{kg} \mathrm{ha}^{-1}$. Except genotype Kornberger, the reason for such a small difference can be explained by the fact that common millet is a self-pollinated plant species that has some genetic material in selection work crossed with each other.

Descriptive statistics for agro-biological traits collection of common millet showed that depending on the studied variables the average value $(\mathrm{I})$, standard deviation $(\mathrm{x} \pm \mathrm{sx})$ and the coefficient of variation (Cv) changed (Table 2). All examined parameters measured by coefficient of variation showed high stability. The lowest values of the coefficient of variation were found in test weight $(\mathrm{Cv}=2.4 \%)$, while the largest variation was between studied genotypes of grain yield of common millet $(\mathrm{Cv}=16.3 \%)$.

\section{Regular and stubble crop}

Millet is a crop of a relatively short growing season, with limited needs for water. Therefore, it is a plant species suitable for growing in areas with hot, dry and short summer season (Baltensperger 2002). In terms of grain yield with $13 \%$ moisture content in regular and stubble crop of common millet, a statistically significant difference was recorded (Table 3). Two-year average grain yields in regular sowing ranged from $1,905 \mathrm{~kg} \mathrm{ha}^{-1}$ for genotype Kornberger to $3,596 \mathrm{~kg} \mathrm{ha}^{-1}$ for genotype NE1. Genotype
Kornberger is widely cultured in Austria and Slovenia, where gives an average of $2,000 \mathrm{~kg} \mathrm{ha}^{-1}$ of grain (Kocjan Ačko 2012). In our research, the difference between the genotypes first ranked NE1 and fourth ranked Sunup was 11.23\%, which is higher than the survey of Baltensperger et al. (1999) who pointed out that the genetic potential of genotype NE1 is up to $4 \%$ higher related to genotype Sunup. The highest yield of $1,936 \mathrm{~kg} \mathrm{ha}^{-1}$ in stubble crop sowing was achieved with genotype Fertodi 2, while, the lowest yield of $969 \mathrm{~kg} \mathrm{ha}^{-1}$ was recorded with genotype Kornberger. The highest yield decrease in stubble crop of $68.33 \%$ was achieved with genotype NE1, less decrease was recorded with genotype Huntsman of $60.23 \%$, while the lowest yield decrease of $45.14 \%$ was recorded with genotype Fertodi 2. Grain yield decrease of millet increased from earlier to later sowing dates, which is particularly evident in periods of land and air drought. Out of 9 varieties and lines of millet, 3 of them achieved a higher yield in stubble crops. Similar results were also obtained by Emendack et al. (2011).

The effect of genotype showed statistical significance in both study years $(\mathrm{p}<0.05)$. Among analysed factors, sowing date had the largest statistically significant difference $\left(\mathrm{F}=360.09^{* *}, \mathrm{Cv}=74.67 \%\right)$, which with the total share in variation participated with $3 / 4$ (Table 4). F value of the analysis of variance for study years had a significant difference in relation to studied genotypes and sowing dates. Analysis of the mutual influence between individual factors and their interaction showed that the interaction variety $\mathrm{x}$ sowing had some higher $\mathrm{F}$ values of analysis of variance and total share in variation $\left(\mathrm{F}=2.71^{\mathrm{NS}}, \mathrm{Cv}=4.51 \%\right)$, which means that there 
Table 3. Millet grain yield $\left(\mathrm{kg} \mathrm{ha}^{-1}\right)$ in regular and stubble crop sowing of common millet Tabela 3. Prinosi zrna $\left(\mathrm{kg} \mathrm{ha}^{-1}\right) \mathrm{u}$ redovnoj i postrnoj setvi običnog prosa

\begin{tabular}{|c|c|c|c|c|c|c|c|c|}
\hline & \multicolumn{4}{|c|}{$\begin{array}{c}\text { Regular sowing / } \\
\text { Redovna setva }\end{array}$} & \multicolumn{4}{|c|}{$\begin{array}{c}\text { Stubble crop sowing / } \\
\text { Postrna setva }\end{array}$} \\
\hline & 2010 & 2009 & $\begin{array}{c}\text { Average / } \\
\text { Prosek }\end{array}$ & $\begin{array}{c}\text { Rank / } \\
\text { Rang }\end{array}$ & 2010 & 2009 & $\begin{array}{c}\text { Average / } \\
\text { Prosek } \\
\end{array}$ & $\begin{array}{r}\text { Rank } / \\
\text { Rang } \\
\end{array}$ \\
\hline Biserka & 3,991 & 3,061 & $3,526^{a}$ & 3 & 1,650 & 1,803 & $1,727^{\mathrm{a}}$ & 2 \\
\hline Rumenka & 3,239 & 2,840 & $3,040^{\mathrm{b}}$ & 5 & 1,607 & 1,184 & $1,396^{\mathrm{b}}$ & 5 \\
\hline Fertodi 2 & 3,510 & 3,547 & $3,529^{a}$ & 2 & 1,892 & 1,979 & $1,936^{a}$ & 1 \\
\hline 9304 & 2,585 & 2,324 & $2,455^{\mathrm{cd}}$ & 8 & 1,213 & 981 & $1,097^{\mathrm{cd}}$ & 8 \\
\hline 9307 & 2,756 & 2,758 & $2,757^{\mathrm{bc}}$ & 7 & 1,638 & 1,322 & $1,480^{\mathrm{a}}$ & 3 \\
\hline NE1 & 3,788 & 3,403 & $3,596^{a}$ & 1 & 1,271 & 1,006 & $1,139^{\mathrm{bc}}$ & 7 \\
\hline Huntsman & 3,223 & 2,550 & $2,887^{\mathrm{bc}}$ & 6 & 1,294 & 1,001 & $1,148^{\mathrm{bc}}$ & 6 \\
\hline Sunup & 3,497 & 2,886 & $3,192^{\mathrm{ab}}$ & 4 & 1,608 & 1,231 & $1,420^{\mathrm{ab}}$ & 4 \\
\hline Kornberger & 1,960 & 1,849 & $1,905^{\mathrm{d}}$ & 9 & 1,018 & 919 & $969^{d}$ & 9 \\
\hline Average / Prosek & 3,172 & 2,802 & 2,987 & & 1,466 & 1,270 & 1,368 & \\
\hline
\end{tabular}

Different letters mark significant differences between varieties, according to Duncan's test, $p \leq 0.05$ Različitim slovima su označene značajne razlike između sorti, prema Dankanovom testu, $p \leq 0.05$

Table 4. Analysis of variance for grain yield $\left(\mathrm{kg} \mathrm{ha}^{-1}\right)$ of common millet in regular and stubble crop sowing Tabela 4. Analiza varijanse za prinos zrna $\left(\mathrm{kg} \mathrm{ha}^{-1}\right)$ običnog prosa u redovnoj i postrnoj setvi

\begin{tabular}{lcc}
\hline $\begin{array}{l}\text { Source of variation / } \\
\text { Izvor varijacije }\end{array}$ & $\begin{array}{c}\text { F value from } \\
\text { analysis of variance / } \\
\text { F vrednost iz analize varijanse }\end{array}$ & $\begin{array}{c}\text { Share in total } \\
\text { variation (\%) / } \\
\text { Udeo u ukupnoj varijaciji }\end{array}$ \\
\hline Variety & $9.920^{* *}$ & 16.47 \\
Sowing & $360.09^{* *}$ & 74.67 \\
Year & $11.08^{* *}$ & 2.28 \\
Variety x sowing & 2.71 & 4.51 \\
Variety x year & 0.54 & 0.89 \\
Sowing x year & 1.04 & 0.22 \\
Variety x sowing x year & 0.58 & 0.96 \\
\hline
\end{tabular}

was a certain effect of these factors to the traits. Statistical analysis showed that other interactions of the first and second order were not statistically significant.

Previous studies of different genotypes of millet pointed to the fact that the cultivated forms of millet achieved better results compared to the wild forms collected from the nature. Depending on the growing areas and environmental conditions, local selections achieved better productive and qualitative characteristics for a longer period of time (Westra \& Callan 1990, Seghatoleslami et al., 2007, Mehrani et al. 2008, Salini et al. 2010, Upadhyaya et al. 2011).

\section{Conclusions}

The variability of yield, plant height, emergence/ earing, 1000-grain weight and test weight between varieties of common millet was very important and it can serve as a good basis for further work on breeding and improving the production, with addition that the existing material should be supplemented with local populations and thus increase genetic diversity as the basis for a successful selection process in relation to tolerance to unfavourable environmental conditions. Sowing date has more significant effect than genotype and environmental conditions in which common millet is grown to the expression 
of basic agro-morphological characteristics: yield, plant height, earliness, 1000-grain weight and test weight. In addition to expanding the genetic basis of the collection, in future work on program of production improvement of common millet, next to sowing date, attention should be paid to the influence of other agro-morphological factors on the components of yield and quality of common millet.

\section{References}

Baltensperger, D.D., Nelson, L.A., Frickel, G.E., \& Anderson, R.L. (1995a). Registration of 'Huntsman' proso millet. Crop Sci. 35, 941.

Baltensperger, D.D., Nelson, L.A., \& Frickel, G.E. (1995b). Registration of 'Earlybird' proso millet. Crop Sci. 35, 1204-1205.

Baltensperger, D.D., Nelson, L.A., Frickel, G.E., \& Anderson, R.L. (1997). Registration of 'Sunrise' proso millet. Crop Sci. 37, 1380.

Baltensperger, D.D., Frickel, G.E., Klein, R.N., Krall, J., Anderson, R., Hain, J., Stymiest, C., Nachtman, J., Nelson, L.A., \& Baenziger, P.S. (1999). EC99-107 Nebraska Proso, Sunflower, Bean, Pea, Oat and Spring Wheat Variety Tests. Historical Materials from University of Nebraska-Lincoln Extension. Paper 1604. Retrieved from http://digitalcommons.unl. edu/extensionhist/1604

Baltensperger, D.D. (2002). Progress with proso, pearl and other millets. In: J. Janick, and A. Whipkey (eds), Trends in New Crops and New Uses, ASHS Press, Alexandria, VA, 100-103.

Baltensperger, D.D., Nelson, L.A., Frickel, G.E., \& Heyduck, R.F. (2004). Registration of 'NE1' proso millet. Crop Sci. 44, 1493-1494.

Barbeau, W.E., \& Hilu, K.W. (1993). Protein, calcium, iron and amino acid content of selected wild and domestical cultivars of finger millet. Plant Foods Human Nutr. 43: 97-104.

Berenji, J., \& Kišgeci, J. (1988). Gajenje kukuruza, sirkova i prosa u postrnoj setvi. 6. Jugoslovenski simpozijum o krmnom bilju, Osijek, 286-291.

Berenji, J. (1990). Millets breeding. 15th Congress of EUCARPIA Maize and Sorghum Section, Baden, Austria, 67.

Berenji, J. (1993). Perspektive gajenja prosa. Zbornik radova Instituta za ratarstvo i pourtarstvo, Novi Sad, 21, 587-598.

Berenji, J. (1994). Značaj i perspektive proizvodnje sirka i prosa. Savremena poljoprivreda, 42(4), 32-36.
Berenji, J., Mirčov, A., \& Jovandić, N. (2000). Nove sorte prosa. In: Jugoslovenski naučno-strućni simpozijum iz. selekcije i semenarstva III JUSEM, Zlatibor, Zbornik izvoda, 175.

Berenji, J., Adamović, D., Sikora, V., \& Sabo, J. (2008). Dostignuća u unapređenju proizvodnje i korišćenja alternativnih kultura u Odeljenju za hmelj, sirak i lekovito bilje Instituta za ratarstvo i povrtarstvo. Zbornik radova Instituta za ratarstvo i pourtarstvo 45(1), 145-158.

Berenji, J. (2012). Contribution of alternative crops to agrobiodiversity. In: Filipović $\mathrm{V}$ and Ugrenović $\mathrm{V}$ (eds.), Organic production and biodiversity. Institute Tamiš, Pančevo, 53-69.

James, T.K., Rahman, A., McGill, C.R., \& Trivedi, P.D. (2011). Biology and survival of broom corn millet (Panicum miliaceum) seed. New Zealand Plant Protection, 64, 142-148.

Cho, Y.I.I., Chung, J.W., Lee, G.A., Ma, K.H., Dixit, A., Gwag, J.G., \& Park, J.Y. (2010). Development and characterization of twenty-five new polymorphic microsatellite markers in proso millet. Genes and Genomics 32(3), 267-273.

Emendack, Y., Herzog, H., Götz, K.P., \& Malinowski, D.P. (2011). Mid-Season water stress on yield and water use of millet (Panicum miliaceum) and sorghum (Sorghum bicolour L. Moench). Australian Journal of Crop Science, 5(11),1486-1492.

Heyduck, R.F., Baltensperger, D.D., Nelson, L.A., \& Graybosch, R.A. (2008). Assessing the stability of agronomic traits in waxy proso (Panicum miliaceum L.) in the Central Great Plains. Crop Sci. 48, 741748.

Hunt, H.V., Campana, M.G., Lawes, M.C., Park, Y.J., Bower, M.A., Howe, C.J., \& Jones, M.K. (2011). Genetic diversity and phylogeography of broomcorn millet (Panicum miliaceum L.) across Eurasia. Mol. Ecol. 20, 4756-4771.

Jacobs, J. (2001). College of Agriculture Agricultural Experiment Station Progress Report 2001. The University of Wyoming. Retrieved from

http://www.uwyo.edu/uwexpstn/_files/docs/ prgrpt01.pdf

James, T.K., Rahman, A., McGill, C.R., \& Trivedi, P. (2011). Biology and survival of broom corn millet (Panicum miliaceum) seed. New Zealand. Plant Protection, 64, 142-148.

Karam, D., Westra, P., Nissen, S.J., Ward, S.M., \& Figueredo, J.E.F. (2004). Genetic diversity among proso millet (Panicum miliaceum) biotypes assessed by AFLP technique. Planta Daninha 22(2), 167174. 
Kocjan Ačko, D. (2012). Importance and possibilities of proso millet (Panicum miliaceum L.) production for human nutrition, and animal feed in Slovenia. Journal of Food, Agriculture \& Environment 10(2), 636-640.

Malešević, M., Denčić, S., Pržulj, N., \& Hristov, N. (2011). Proizvodnja semena strnih žita. (pp. 11-88). In M. Milošević, B. Kobiljski (eds.), Semenarstvo Vol. 2. Institut za ratarstvo i povrtarstvo, Novi Sad.

Manoharan, V., \& Sivasubramanian, V. (1982). Variability studies in proso millet (Panicum miliaceum L.). Madras Agricultural Journal, 69(5), 343-345.

Mehrani, A., Mosavat, S.A., \& Shoshi, A.A. (2008). Comparison of common millet (Panicum miliaceum) encouraging cultivars for grain yield, dry matter and some morphological traits in 3 different climatic zone. Pajoubesh and Sazandegi 21(3), 25-32.

Popović, V., Malešević, M., Miladinović, J., Marić, V., \& Živanović, Lj. (2013). Effect of agroecological factors on variations in yield, protein and oil contents in soybean grain. Roman. Agric. Res. 30, In press, DII 2067-5720.

Salini, K., Nirmalakumari, A., Muthiah, A.R., \& Senthil, N. (2010). Evaluation of proso millet (Panicum miliaceum L.) germplasm collections. Electronic Journal of Plant Breeding 1(4), 489-499.
Seghatoleslami, M.J., Kafi, M., Majidi, I., Nour-Mohammadi, G., \& Darvish, F. (2007). Effect of drought stress at different growth stages on yield and water use efficiency of five proso millet (Panicum miliaceum) genotypes. JWSS-Isfahan University of Technology, 11(1), 215-227.

Sikora, V., Berenji, J., \& Latković, D. (2011). Influence of agroclimatic conditions on content of main cannabinoids in industrial hemp. Genetika, 43(3), 229-236.

Starčević, Lj., \& Berenji, J. (1994). Mesto i uloga prosolikih žita u proizvodnji hrane. Savremena poljoprivreda, 42(4), 7-11.

Upadhyaya, H.D., Shivali Sharma, C.L.L., Gowda, V., Reddy, G., \& Singh, S. (2011). Developing proso millet (Panicum miliaceum L.) core collection using geographic and morpho-agronomic data. Crop and Pasture Science, 62(5), 383-389.

Westra, P., \& Callan, M. (1990). Morphological and reproductive characteristics of fifteen wild proso millet (Panicum miliaceum) accessions from the United States and Canada. Res. Prog. Report West. Soc. Weed Sci., 405-407.

Zeller, F.J. (2000). Nutzung, Genetik und Züchtung kleinkörniger Hirsegräser: 3. Rispenhirse (Panicum miliaceum L.). J. Appl. Bot. 74, 182-186.

\title{
Agrobiološke osobine različitih genotipova običnog prosa (Panicum miliaceum L.) u redovnoj i postrnoj setvi
}

\author{
Vladimir Sikora • Vladimir Filipović • Janoš Berenji • Vera Popović
}

Izvod: Na oglednim parcelama Instituta za ratarstvo i povrtarstvo, Novi Sad, u Bačkom Petrovcu u toku 2009. i 2010. istraživane su agrobiološke osobine različitih genotipova običnog prosa (Panicum miliaceum L.). U istraživanja je bilo uključeno 16 genotipova prosa koje se gaje i koriste u selekcijskim programima kod nas i u svetu. Usev u ogledima zasnovan je u redovnoj i postrnoj setvi. U toku i na kraju vegetacije utvrđena je značajna varijabilnost broja dana od nicanja do klasanja pojedinih genotipova prosa, visine biljke, prinosa zrna, mase 1000 zrna i hektolitarske masa ispitivanog materijala i ona može poslužiti kao dobra osnova za dalji rad na oplemenjivanju i unapređenju proizvodnje običnog prosa. Klaster analiza identifikovala je genotipove sa visokim performansama za prinos po biljci ali i dobre stabilnosti ostalih ispitivanih parametara. Istraživanja su pokazala da je genetski faktor bio veoma značajnog uticaja ostvarene vrednosti svih ispitivanih svojstava. Razlike između prinosa zrna prosa u redovnoj i postrnoj setvi takođe su bile statistički značajne. Od 9 sorti i linija prosa, tri su postigle viši prinos u postrnoj setvi. Sa aspekta agrobioloških osobina 2010. je bila povoljnija godina za proizvodnju prosa.

Ključne reči: agrobiološke osobine, genotip, klaster analiza, obično proso, postrni usevi, prinos useva 